\title{
The Age of Multilevel Converters Arrives
}

\author{
Leopoldo G. Franquelo, IEEE Fellow, Jose Rodríguez, IEEE Senior Member, Jose I. Leon, IEEE \\ Member, Samir Kouro, IEEE Student Member, Ramon Portillo, IEEE Student Member, Maria M. \\ Prats, IEEE Member
}

\section{INTRODUCTION}

$C_{\text {to }}^{\text {ure }}$ urrent energy arena is changing. The feeling of dependence on fossil fuels and the progressive increase of its cost is leading to the investment of huge amount of resources, economical and human, to develop new cheaper and cleaner energy resources not related to fossil fuels. In fact since decades, renewable energy resources have been the focus for researchers and different families of power converters have been designed to make the integration of this type of systems into the distribution grid a current reality. Besides, in the transmission lines, high power electronic systems are needed to assure the power distribution and the energy quality. Therefore, power electronic converters have the responsibility to carry out these tasks with high efficiency.

The increase of the world energy demand has entailed the apparition of new power converter topologies and new semiconductors technology capable to drive all needed power. A continuous race to develop higher voltage and current power semiconductors to drive high power systems still goes on. In this way, the last generation devices are suitable to support high voltages and currents (around $6.5 \mathrm{kV}$ and $2.5 \mathrm{kA}$ ). However, currently there is a tough competition between the use of classic power converter topologies using high voltage semiconductors and new converter topologies using medium voltage devices. This idea is shown in Fig. 1, where multilevel converters built using mature medium power semiconductors are fighting in a development race with classic power converters using high power semiconductors which are under continuous development and are not mature. Nowadays, multilevel converters are a good solution for power applications due to the fact that they can achieve high power using mature medium power semiconductors technology [1][2].

Multilevel converters present great advantages compared with typical and very well known two-level converters [1],[3]. These advantages are fundamentally focused on improvements in the output signals quality and a nominal power increase in the converter. In order to show the improved quality of the output voltages of a multilevel converter, the output voltages of a singlephase two level converter is compared to a 3 and 9 level multilevel waveform in Fig. 2. The power converter output voltage improves its quality as the number of levels increases reducing the Total Harmonic Distortion of the system.

These properties make multilevel converters very attractive to the industry and nowadays, researchers all over the world are spending great efforts trying to improve multilevel converter performances such as the control simplification [4][5] and the performance of different optimization algorithms in order to enhance the Total Harmonic Distortion (THD) of the output signals [6][7], the balancing of the DC capacitors voltage [8][9], the ripple of the currents [10][11]. For instance, nowadays researchers are focused on the harmonic elimination using pre-calculated switching functions [12], harmonic mitigation to fulfill specific grid codes [13], the development of new multilevel converter topologies (hybrid or new ones) [14] and new control strategies 
[15][16].

The most common multilevel converter topologies are: Neutral-Point-Clamped Converter (NPC) [17], Flying Capacitor Converter (FC) [18], and Cascaded H-Bridge Converter (CHB) [19]. These converters can be classified among the power converters for high power applications according to Fig. 3. Several surveys on multilevel converters have been published to introduce these topologies [1][2]. In 1980s, power electronics concerns were focused on the converters power increase (increasing voltage or current). In fact, current source inverters were the main focus for researchers in order to increase the current. However, other authors began to work on the idea of increasing the voltage instead the current. In order to achieve this objective, authors were developing new converter topologies and in 1981, A. Nabae, I. Takahashi and H. Akagi presented the first Neutral-Point-Clamped PWM converter (NPC) also named diode-clamped converter [17]. This converter was based on a modification of the classic two-level converter topology adding two new power semiconductors per phase (see Fig. 1). Using this new topology, each power device has to tolerate at the most half voltage compared with the two-level case with the same DCLink voltage. So, if these power semiconductors have the same characteristics than the two-level case, the voltage can be doubled. The NPC converter was generalized in [21],[22] in order to increase the number of output levels, and was referred as multi-point clamped converter (MPC), although it has not reached the medium voltage market jet.

Years later, other multilevel converter topologies as the FC [18] or CHB [19],[20] appeared. These multilevel converters present different characteristics compared with NPC as the number of components, modularity, control complexity, efficiency and fault tolerance. Depending on the application, the multilevel converter topology can be chosen taking into account these factors as it is shown in Table I.

TABLE I

COMPARISON OF MULTILEVEL CONVERTER TOPOLOGIES DEPENDING ON IMPLEMENTATION FACTORS

\begin{tabular}{cccc}
\hline \hline Number of \\
components & $\begin{array}{c}\uparrow \text { switches } \\
\uparrow \text { diodes }\end{array}$ & $\begin{array}{c}\uparrow \text { switches } \\
\uparrow \text { capacitors } \\
\downarrow \text { diodes }\end{array}$ & $\begin{array}{c}\downarrow \text { Cwwitches } \\
\downarrow \text { diodes } \\
\text { isolated DC } \\
\text { sources }\end{array}$ \\
\hline Modularity & Low & High & High \\
\hline $\begin{array}{c}\text { Control } \\
\text { complexity }\end{array}$ & Medium & High & High \\
\hline Control concerns & $\begin{array}{c}\text { Voltage } \\
\text { balancing }\end{array}$ & Voltage setup & $\begin{array}{c}\text { Power } \\
\text { sharing }\end{array}$ \\
\hline Fault tolerance & Difficult & Easy & Easy \\
\hline \hline
\end{tabular}

Nowadays, there are several commercial multilevel converter topologies which are sold as industrial products for high power applications [23]-[25]. However, although the advantages of using multilevel converters have been demonstrated, there has not been an industrial boom in the application of these power systems in the electrical grid in spite of their demonstrated good features to be used as medium voltage drives. Maybe, technological problems as reliability, efficiency, the increase of the control complexity and the design of simple and fast modulation methods have been the barrier that has slowed down the application of multilevel converters all over the world. Finally, the effort of researchers has overcome this technical barrier and it can be affirmed that multilevel converters are prepared to be applied as a mature power system in the electric energy arena.

This work is devoted to review and analyze the most relevant characteristics of multilevel converters, to motivate possible solutions, and to show that we are in a decisive instant in which energy companies have to bet for these converters as a good solution compared with classic two-level converters. The paper is organized as follows. In section II, a brief overview of the actual applications of multilevel converters is presented. An introduction of the modeling techniques and the most common modulation strategies is respectively presented in sections III and IV. Finally, the operational and technological issues have been addressed in section $\mathrm{V}$ and some conclusions are presented in last section. 


\section{MULTILEVEL CONVERTER DRIVEN APPLICATIONS}

Multilevel converters are considered today as a very attractive solution for medium voltage high power applications. In fact, several major manufacturers commercialize NPC, FC or CHB topologies with a wide variety of control methods, each one strongly depending on the application. Particularly the NPC has found an important market in more conventional high power ac motor drives applications like conveyors, pumps, fans and mills among others, which offer solutions for industries including oil and gas, metals, power, mining, water, marine and chemistry [26][27].

The back to back configuration for regenerative applications has been also a major hit of this topology, used for example in regenerative conveyors for the mining industry [28], or grid interfacing of renewable energy sources, like wind power [29][30]. On the other hand FC converters have found particular applications for high bandwidth - high switching frequency applications such as medium voltage traction drives [31]. Finally the cascaded H-bridge has been successfully commercialized for very high power and power quality demanding applications up to a range of 31MVA, due to its series expansion capability. This topology has also been reported for active filter and reactive power compensation applications [32], electric and hybrid vehicles [33][34], photovoltaic power conversion [35]-[37], uninterruptible power supplies [38], and Magnetic Resonance Imaging [39]. As an example of a commercial multilevel power converter a 34kV-15MW three-phase six-cell CHB converter from SIEMENS for regenerative drives is shown in Fig. 4. A summary of multilevel converter driven applications is illustrated in Fig. 5.

\section{MODELS: A TOOL TO ENHANCE MULTILEVEL CONVERTER POSSIBILITIES}

The simulation and the determination of "Input to Output (I/O)" relations are a fundamental task in the study and design process of the multilevel converters. These I/O relations become essential for the development of suitable models which allow to obtain all the necessary information about the converter previously to the implementation stage. The modeling of multilevel converters is not a trivial task since they are made up of linear and non linear components. Historically, modeling techniques applied to DC power electronics converters have been adapted to be used in the study of AC ones, giving place to different approximations that achieve, according to their objectives, snubber circuits design, control schemes and controllers development, steady state study, dynamic and transient response study, stability analysis, etc. The operation of the multilevel converter is a periodic sequencing of its possible states corresponding to discrete states of the switches. Fig. 6 shows a three-level NPC phase has and the two possible modeling techniques. Taken these remarks into account, two types of models can be developed: equivalent circuit simulation or state-space averaged.

\section{A. Circuit Simulation Modeling of Multilevel Converters}

A model of the converter can be obtained with the help of powerful simulation tools as SPICE-based simulators. In this case, the modeling of the multilevel converters is reduced to the generation of an adequate electric circuit model that fully includes the non-linearities of the switches allowing the complete characterization of the system dynamic. Considering ideal switches, a linear description of the converter can be obtained for every switching state of the power converter. Fig. 6 shows a phase of the threelevel diode-clamped converter where the switches have been replaced by an ideal switch and can be easily seen that the phase acts like a voltage source for every switch position so a linear equivalent circuit description of the converter phase can be obtained for each one. With this model, a linear piecewise simulation can be carried out. If the integration method for the model equations is properly chosen [40], the simulation time and results accuracy are good enough. However, this modeling approach often leads to large simulation times and possible unreliable results due to convergence problems. The main drawbacks of this modeling technique are that the integration of advanced control techniques with the model is almost impossible [40] and that the 
model is usually complex being its use for control design often troublesome [41][42]. These models can be used in the tuning process of the control loops and to evaluate the high order harmonics due to switching that can be easily seen on currents shown in Fig. 6.

\section{B. State-Space Averaged Modeling of Multilevel Converters}

State-space averaged models can be easily obtained from the discrete ones when varying quantities are assumed as their averaged value over a switching period, remaining the DC value of those quantities. Since in AC converters these quantities are time varying even in the steady state, it is necessary to make a change of coordinates to convert AC sinusoidal quantities to DC quantities previously to the averaging process [43][44]. Time invariant systems controller design techniques can be used with these models when important components other than the fundamental harmonic are not present in the system. With the transformation to this "Rotating Reference Frame" DC quantities corresponds to the fundamental harmonic of the signals, but some multilevel converter topologies are not completely characterized by only the first harmonic and it is necessary to draw on to "Harmonic models" where a greater number of harmonics are taken into account obtaining an adequate modeling of the converter [41]. These "Harmonic models" are complex and only some advanced complex control techniques are suitable to be applied to them [42].

Recently a new state-space averaging modeling technique has been introduced based on approximations over the exact averaged linear piecewise characteristics of the converter [30]. In the phase of the three-level diode-clamped converter shown in

Fig. 6, the ideal switch will be switching between the three possible states so an average model can be deduced considering $\delta_{a}$ as the averaged value of the switch position. Fig. 6 shows the graphic representation of the exact averaged linear piecewise approximation and the proposed quadratic approximation [29]. This technique provides simple enough models to be used in the controller design [45] and carries out fast simulations without convergence problems due to the continuous nature of the obtained equations. Therefore, the use of these models overcomes one of the technological handicaps in which the multilevel converters are involved, making the design stage of multilevel power systems a more accessible task. Fig. 6 shows the currents obtained with this kind of model and when compared with those obtained with the equivalent circuit simulation it can be seen that the results are almost the same except for the high order harmonics.

\section{MULTILEVEL MOdULATION METHODS}

Multilevel inverter modulation and control methods have attracted much research and development attention over the last decade [1][2][46][47]. Among the reasons are: the challenge to extend traditional modulation methods to the multilevel case, the inherent additional complexity of having more power electronics devices to control, and the possibility to take advantage of the extra degrees of freedom provided by the additional switching states generated by these topologies. As consequence, a large number of different modulation algorithms have been developed, each one with unique features and drawbacks, depending on the application.

A classification of the modulation methods for multilevel inverters is presented in Fig. 7. The modulation algorithms are divided into two main groups depending on the domain in which they operate: the state space vector domain in which the operating principle is based on the voltage vector generation, and the time domain in which the method is based on the voltage level generation over a time frame. In addition, in Fig. 7 the different methods are labeled depending on the switching frequency they produce. In general, low switching frequency methods are preferred for high power applications due to the reduction of switching losses, while the better output power quality and higher bandwidth of high switching frequency algorithms are more 
suitable for high dynamic range applications.

\section{A. Multilevel Converters PWM strategies}

Traditional Pulse Width Modulation (PWM) techniques [48] have been successfully extended for multilevel converter topologies, by using multiple carriers to control each power switch of the converter. Therefore, they are known as Multicarrier PWM methods as shown in Fig. 7. For multicell topologies, like FC and CHB, each carrier can be associated to a particular power cell to be modulated independently using sinusoidal bipolar PWM and unipolar PWM respectively, providing an even power distribution among the cells. For a converter with $\mathrm{m}$ cells, a carrier phase shift of $180^{\circ} / \mathrm{m}$ for the CHB and of $360^{\circ} / \mathrm{m}$ for the FC is introduced across the cells to generate the stepped multilevel output waveform with low distortion [23]. Therefore this method is known as Phase Shifted PWM (PS-PWM). The difference between the phase shifts and the type of PWM (unipolar or bipolar) is because one CHB cell generates 3-level outputs, while one FC cell generates two level outputs. This method naturally balances the capacitor voltages for the $\mathrm{FC}$, and also mitigates input current harmonics for the $\mathrm{CHB}$.

The carriers can also be arranged with shifts in amplitude relating each carrier with each possible output voltage level generated by the inverter. This strategy is known as Level Sifted PWM (LS-PWM), and depending on the disposition of the carriers, they can be in Phase Disposition (PD-PWM), Phase Opposition Disposition (POD-PWM) and Alternate Phase Opposition Disposition (APOD-PWM) [49], all shown in Fig. 7.

A in depth assessment between these PWM methods can be found in [50]. LS-PWM methods can be implemented for any multilevel topology, however, they are more suited for the NPC, since each carrier signal can be easily related to each power semiconductor. Particularly LS-PWM methods are not very attractive for CHB inverters, since the vertical shifts relate each carrier and output level to a particular cell, producing an uneven power distribution among the cells. This power unbalance disables the input current harmonic mitigation that can be achieved with the multipulse input isolation transformer, reducing the power quality.

Finally, the hybrid modulation is in part a PWM based method which is specially conceived for the CHB with unequal dc sources [14],[51]-[53]. The basic idea is to take advantage of the different power rates among the cells of the converters to reduce switching losses and improve the converter efficiency. This is achieved by controlling the high power cells at fundamental switching frequency by turning on and off each switch of each cell only one time per cycle, while the low power cell is controlled using unipolar PWM. Also asymmetric or hybrid topologies have been proposed based on the MPC structure [54].

\section{B. Space Vector Modulation techniques}

Space Vector Modulation (SVM) is a technique where the reference voltage is represented as a reference vector to be generated by the power converter. All the discrete possible switching states of the converter lead to discrete output voltages and they can be also represented as the possible voltage vectors (usually named state vectors) that can be achieved. SVM technique generates the voltage reference vector as a linear combination of the state vectors obtaining an averaged output voltage equal to the reference over one switching period [55].

In the last years, several space vector algorithms extended to multilevel converters have been found in bibliography. Most of them are particularly designed for a specific number of levels of the converter and the computational cost and the algorithm complexity are increased with the number of levels. Besides, these general modulation techniques for multilevel converters involve trigonometric function calculations, look-up tables or coordinated system transformations which increases the computational load.

Recent SVM strategies have drastically reduced the computational effort and the complexity of the algorithms compared with 
other conventional SVM and sinusoidal PWM modulation techniques [56]-[62]. A survey of recent SVM algorithms for power voltage source multilevel converters was presented in [63]. These techniques provide the nearest state vectors to the reference vector forming the switching sequence and calculating the corresponding duty cycles using extremely simple calculations without involving trigonometric functions, look-up tables or coordinate system transformations which increase the computational effort corresponding to the modulation of a multilevel converter. Therefore, these methods drastically reduce the computational load maintained permitting the on-line computation of the switching sequence and the on-state durations of the respective switching state vectors. In addition, the low computational cost of the proposed methods is always the same and it is independent of the number of levels of the converter.

The three dimensional SVM (3D-SVM) technique presented in [59] is a generalization of the well known 2D-SVM strategy [60] used when the power system is balanced (without triple harmonics) and therefore the state vectors are located in a plane (alpha-beta plane). However, it is necessary to generalize to a 3D space if the system is unbalanced or if there is zero sequence or triple harmonics because in this case state vectors are not on a plane. 3D-SVM technique for multilevel converters is successfully used for compensating zero sequence in active power filters with neutral with single-phase distorting loads which generate large neutral currents. In general, 3D-SVM is useful in systems with or without neutral, unbalanced load, triple harmonics and for generating whatever three-dimensional control vector. Moreover, this technique also permits to balance the DC-link capacitors voltage.

The strategy proposed in [59] is the first 3D-SVM technique for multilevel converters which permits the on-line calculation of the sequence of the nearest space vector for generating the reference voltage vector. The computational cost of the proposed method is very low and it is independent of the number of levels of the converter. This technique can be used as modulation algorithm in all applications which provide a 3D vector control.

Finally, four-leg multilevel converters are finding relevance in active power filters and fault-tolerant three-phase rectifiers with capability for load balancing and distortion mitigation thanks to their ability to meet the increasing demand of power ratings and power quality associated with reduced harmonic distortion and lower EMI [64][65]. A four-leg multilevel converter permits a precise control of neutral current due to an extended range for the zero sequence voltages and currents.

A generalized and optimized 3D-SVM algorithm for four-leg multilevel converters has been recently presented in [66]. The proposed technique directly allows the optimization of the switching sequence minimizing the number of switching in four-leg systems. As in [56]-[61], the computational complexity has been reduced up to minimum. This technique can be used as modulation algorithm in all applications needing a 3D control vector such as four-leg active, where the conventional 2D-SVM can not be used.

\section{Other Multilevel Modulation Algorithms}

Although SVM and Multicarrier PWM are widely accepted and have reached a certain maturity for multilevel applications, other algorithms have been developed to satisfy particular needs of different applications. Selective Harmonic Elimination (SHE), for example, has been extended to the multilevel case for high power applications due to the strong reduction in the switching losses [6][12][67]. However, SHE algorithms are very limited to open-loop or low-bandwidth applications, since the switching angles are computed offline and stored in tables, which are then interpolated according to the operating conditions. In addition, SHE based methods become very complex to design and implement for converters with high number of levels (above five), due to the increase of switching angles, hence equations, that need to be solved. In this case, other low switching frequency methods are more suitable. For example, multilevel Space Vector Control (SVC) takes advantage of the high number voltage vectors generated by a converter with high number of levels, by approximating the reference to the closest generable vector [68]. This 
principle results in a natural fundamental switching frequency with reduced switching losses, like in SHE, that can be easily implemented in closed-loop and high-bandwidth systems. The time domain version of SVC, is the Nearest Level Control (NLC), which in essence is the same principle but considering the closest voltage level that can be generated by the inverter instead of the closest vector [69]. Both methods, are suitable for inverters with high number of levels, since the operating principle is based on an approximation and not a modulation with a time average of the reference, and also due to the low and variable switching frequency, they present higher total harmonic distortion for inverter with lower number of levels and also for low modulation indexes.

As mentioned before not all the modulation schemes mentioned before and illustrated in Fig. 7 are suitable for each topology, moreover some algorithms are not applicable to some converters. Fig. 8 summarizes the compatibility between the modulation methods and the multilevel topologies.

\section{OPERATIONAL AND TECHNOLOGICAL ISSUES}

Multilevel converters offer very attractive characteristics for high power applications, however the power circuit of the multilevel topologies have more complex structures than classic converters and sometimes their operation is not straightforward, and particular problems need to be addressed. In other occasions this extra complexity can also be embraced as an opportunity to introduce enhanced operating characteristics like efficiency, power quality and fault tolerant operation, which are not feasible in classic topologies.

One of the most analyzed and extensively addressed drawbacks of multilevel technology is the neutral point control or capacitor voltage balance necessary for NPC converters. The NPC experiments a capacitor unbalance for certain operating conditions, depending on the modulation index, dynamic behavior and load conditions among others, which produce a voltage difference between both capacitors, shifting the neutral point and causing undesirable distortion at the converter output. This drawback has been addressed in many works for different modulation methods, both in vector and time domain [70]-[74], and is widely accepted as a solved problem. The neutral point control of NPC converters and the power circuit structure becomes even more complex for non traditional configurations with more output levels (five and up), especially due to the amount of clamping diodes needed. Therefore mainly three-level NPC converters are found on the market.

FC converters, on the contrary have a natural voltage balancing operation [31] but the capacitor voltages have to be pre-charged at startup close to their nominal values, also know as initialization. This can be performed via an additional and simple control logic of the switches of the converter by connecting successively each capacitors to the source and disconnect them when the desired voltage is reached. Although the topology is modular in structure and can be increased in an arbitrary number of cells, the additional flying capacitors and the involved costs has kept traditional configurations up to about four levels. In addition, more cells do not necessarily signify an increase of the power rating of the converter, since the output voltage amplitude does not vary, only the number of levels, hence the power quality.

CHB converters, have also no voltage balancing problems due to the independent and isolated dc-sources provided by the multipulse secondary windings of the input transformer. Furthermore, it does not need special initialization, and its circuit structure enables series connection to reach power levels for very high power applications (maximum rates $13.8 \mathrm{KV}, 1400 \mathrm{~A}$ and $31000 \mathrm{KVA}$ ), where it has found industrial acceptance. However, the isolation transformer is non standard due to the amount of secondaries, and to the angle shifts between windings for input current harmonic mitigation. This is an important drawback that has kept this topology with a smaller market penetration. Nevertheless, transformer-less applications, like photovoltaic power conversion, active filters and battery powered electric vehicles, have been reported as suitable applications [32]-[39]. The 
complicated transformer has also been avoided using a standard transformer to power only one cell (per phase) of the converter, and use the control strategy to control the circulating power to keep the other power cells dc-links charged at desired values [76].

For the case of CHB with unequal dc-sources, the same drawback of the equally fed case apply, with the difference that the input transformer has even power rate differences between windings, and in addition no input current harmonic compensation is achieved. Another drawback is the loss of modularity since the asymmetric power distribution between cells forces different ratings of the components (mainly the voltage rate of the capacitors and semiconductors). Nevertheless, these topologies offer very high power quality waveforms with less power semiconductors (reduction in size and cost, while increase in reliability), and lower switching losses, since the high power cells only commutate at fundamental switching frequency. Moreover, the complicated transformer can be avoided by similar control strategies applied to the symmetric case, or in transformer-less applications (specially active filters). Another issue with the asymmetric CHB is that the low power cells regenerate power during some operating conditions (they vary depending on the asymmetry, the modulation index, and the load), even if the power converter is in motoring mode [77]. If this power is not handled appropriately by using an active front end rectifier or by resistive dissipation, the lower power cells dc-link voltages will drift and become unbalanced generating output voltage distortion. This problem can be minimized using appropriate voltage asymmetries between the cells [14].

Although common mode voltages and bearing currents are strongly reduced when using multilevel converters, due to the reduced $\mathrm{dv} / \mathrm{dt}^{\prime} \mathrm{s}$ and more sinusoidal outputs, this is still a subject under research, and several contributions have been reported [78]-[81].

Since CHB and FC have a modular structure, they can be more directly adapted to operate under internal fault conditions. This is a very attractive capability for industry applications, specially considering those downtimes (and the associated costs) can be avoided, or greatly reduced while a more organized and scheduled reparation is prepared. Fault operation is only possible if the malfunction is properly and timely detected, making the fault diagnostic an important issue. Several contributions have been reported, from simply bypassing faulty cells to more complex reference pre-compensation methods for enhanced operation [82][85]. Different fault detection mechanisms have also been reported, for example, based on the spectral analysis of the carrier and sidebands harmonics of the output voltage [86], [87].

Although the three main topologies analyzed in the paper present unique features and drawbacks, making each one special for a particular application, they have been compared in terms of structure, cost, and efficiency in [88].

\section{CONCLUSIONS}

Multilevel converters have matured from being an emerging technology to a well established and attractive solution for medium voltage high power drives. As it was presented along this paper, these converters have overcome the technical barriers which had been the curb for their deep use as an optimized solution in the power market. Modeling, control strategies design and modulation methods development have been introduced in last years to carry out this technical revolution. Nowadays multilevel converter topologies as NPC, FC and CHB own very interesting features in terms of power quality, power range, modularity and other characteristics achieving high quality output signals being specially designed for medium and high power applications. Therefore, it's the time for betting on this technology for actual and future power applications just now when the market is step to step going forward more powerful and distributed energy sources. The current trends and challenges faced by energy applications, such as renewable power conversion and distributed generation systems, together with the recent developments in multilevel converter technology are opening a new vast area of applications where this technology has a lot to offer. It is just a 
question of time before multilevel converters will reach an important market share in these applications. You could say its time for multilevel converters...

\section{REFERENCES}

[1] J. Rodriguez, Jih-Sheng Lai and Fang Zheng Peng, "Multilevel inverters: a survey of topologies, controls, and applications," IEEE Trans. on Industrial Electronics, vol. 49, Issue 4, Aug. 2002, pp. $724-738$.

[2] Jih-Sheng Lai and Fang Zheng Peng, "Multilevel converters-a new breed of power converters", IEEE Transactions on Industry Applications, vol. 32, Issue 3, May-June 1996, pp. $509-517$.

[3] J. Rodriguez, S. Bernet, B. Wu, J. Pontt, S. Kouro, "Multilevel Voltage-Source-Converter Topologies for Industrial Medium-Voltage Drives," IEEE Transactions on Industrial Electronics, vol. 54, no. 6, Dec. 2007, pp. 2930-2945.

[4] A. BenAbdelghani, C.A. Martins, X. Roboam and T.A. Meynard, "Use of extra degrees of freedom in multilevel drives," IEEE Transactions on Industrial Electronics, vol. 49, Issue 5, Oct. 2002, pp. $965-977$.

[5] Zhiguo Pan, Fang Zheng Peng, K.A. Corzine, V.R. Stefanovic, J.M. Leuthen and S. Gataric, "Voltage balancing control of diode-clamped multilevel rectifier/inverter systems," IEEE Transactions on Industry Applications, vol. 41, Issue 6, Nov.-Dec. 2005, pp. 1698 - 1706.

[6] B. Ozpineci, L.M. Tolbert and J.N. Chiasson, "Harmonic optimization of multilevel converters using genetic algorithms," IEEE Power Electronics Letters, vol. 3, Issue 3, Sept. 2005, pp. $92-95$.

[7] B.P. McGrath, D.G. Holmes and T. Meynard, "Reduced PWM harmonic distortion for multilevel inverters operating over a wide modulation range," IEEE Transactions on Power Electronics, vol. 21, Issue 4, July 2006, pp. 941 - 949.

[8] M. Marchesoni and P. Tenca, "Diode-clamped multilevel converters: a practicable way to balance DC-link voltages," IEEE Transactions on Industrial Electronics, vol. 49, Issue 4, August 2002, pp. $752-765$.

[9] K.A. Corzine and X. Kou, "Capacitor voltage balancing in full binary combination schema flying capacitor multilevel inverters," IEEE Power Electronics Letters, vol. 1, Issue 1, March 2003, pp. $2-5$.

[10] M. Marchesoni, "High-performance current control techniques for application to multilevel high-power voltage source inverters," IEEE Transactions on Power Electronics, vol. 7, Issue 1, January 1992, pp. $189-204$.

[11] A. Bendre and G. Venkataramanan, "Neutral current ripple minimization in a three-level rectifier," IEEE Transactions on Industry Applications, vol. 42, Issue 2, March-April 2006, pp. $582-590$.

[12] Zhong Du, L.M. Tolbert and J.N. Chiasson, “Active harmonic elimination for multilevel converters," IEEE Transactions on Power Electronics, vol. 21, Issue 2, March 2006, pp. $459-469$.

[13] L. G. Franquelo, J. Napoles, R. Portillo, J. I. Leon and M. Aguirre, "A Flexible Selective Harmonic Mitigation Technique to Meet Grid Codes in ThreeLevel PWM Converters”, IEEE Transactions on Industrial Electronics, Volume 54, Issue 6, Dec. 2007, pp. 3022 - 3029.

[14] C. Rech and J.R. Pinheiro, "Hybrid Multilevel Converters: Unified Analysis and Design Considerations," IEEE Transactions on Industrial Electronics, vol. 54, Issue 2, April 2007, pp. 1092 - 1104.

[15] L. Yacoubi, K. Al-Haddad, L.-A. Dessaint, F. Fnaiech, "Linear and Nonlinear Control Techniques for a Three-Phase Three-Level NPC Boost Rectifier," Trans. on Industrial Electronics, vol. 53, no. 6, pp. 1908-1918, Dec 2006.

[16] Pablo Lezana, Csar A. Silva, Jos Rodrguez, Marcelo A. Prez, "Zero-Steady-State-Error Input-Current Controller for Regenerative Multilevel Converters Based on Single-Phase Cells," Trans. on Industrial Electronics, vol. 54, no. 2, pp. 733-740, April 2007.

[17] A. Nabae, I. Takahashi and H. Akagi, “A neutral-point clamped PWM inverter,” IEEE Transactions on Industry Applications, vol. 1A-17, No. 5, Sep-Oct 1981, pp. 518-523.

[18] T.A. Meynard and H. Foch, "Multi-level choppers for high voltage applications", in Proc. European Conference on Power Electronics and Applications, vol. 2, 1992, pp. 45-50.

[19] M. Marchesoni, M. Mazzucchelli, and S. Tenconi, “A nonconventional power converter for plasma stabilization”, IEEE Transactions on Power Electronics, vol. 5, 1991, pp. 212-219.

[20] T. Ghiara, M. Marchesoni, L. Puglisi, G. Sciutto, A modular approach to converter design for high power AC drives, Proceedings of the 4th European Conf. on Power Electronics and Applications (EPE '91), Firenze, Italy, 3-6 September, 1991, pp. 4-477/4-482,

[21] N.S. Choi, J.G. Cho, G.H. Cho, “A general circuit topology of multilevel inverter”, PESC’91 Conf. Rec., Cambridge, Massachusetts, June 1991, pp. 96103. 
[22] M.Carpita, M.Fracchia, S.Tenconi, “A novel multilevel structure for voltage source inverter”, Proc. of the EPE '91 Conf., Firenze, Italy, September 1991, pp.1-090/1-094.

[23] B. Wu, "High Power Converters and AC Drives", IEEE Press \& John Wiley, October 2005, ISBN: 0-4717-3171-4.

[24] P. K. Steimer, "High power electronics, trends of technology and applications", keynote in Power Electronics, Intellingent motion and Power Quality, PCIM'07, Nuremberg, Germany.

[25] N. Zargari and S. Rizzo, "Medium Voltage Drives in Industrial Applications," Technical Seminar, IEEE Toronto Section, 37 pages, November 2004.

[26] R.D. Klug and N. Klaassen, "High Power Medium Voltage Drives - Innovations, Portfolio, Trends," in Proc. Conf. Rec. of EPE, Dresden, 2005.

[27] S. Bernet, "State of the Art and Developments of Medium Voltage Converters - An Overview," Przeglad Elektrotechniczny (Electrical Review), Vol. 82, No. 5, May 2006, pp. 1-10.

[28] J. Rodríguez, J. Pontt, G. Alzamora, N. Becker, O. Einenkel and A. Weinstein, "Novel 20 MW Downhill Conveyor System Using Three-Level Converters," IEEE Transactions on Industrial Electronics, vol. 49, no. 5, October 2002, pp. 1093-1100.

[29] S. Alepuz, S. Busquets-Monge, J. Bordonau, J. Gago, D. Gonzalez, J. Balcells, "Interfacing Renewable Energy Sources to the Utility Grid Using a ThreeLevel Inverter", IEEE Transactions on Industrial Electronics, Vol. 53, Issue 5, Oct. 2006, pp. $1504-1511$.

[30] R.C. Portillo, M.M. Prats, J.I. Leon, J.A. Sanchez, J.M. Carrasco, E. Galvan and L.G. Franquelo, "Modeling Strategy for Back-to-Back Three-Level Converters Applied to High-Power Wind Turbines", IEEE Transactions on Industrial Electronics, Vol. 53, Issue 5, Oct. 2006, pp.1483 - 1491.

[31] T. Meynard, H. Foch, P. Thomas, J. Cournault, R. Jakob and M. Nahrstaedt, "Multicell Converters: Basic Concepts and Industry Applications", IEEE Transactions on Industrial Electronics, vol. 49, no. 5, October 2002, pp. 955-964.

[32] J. Dixon, L. Moran, E. Rodriguez and R. Domke, "Reactive power compensation technologies: state-of-the-art review", Proceedings of the IEEE, vol. 93, no. 12, December 2005, pp. 2144- 2164.

[33] L.A. Tolbert, Fang Zheng Peng, T.Cunnyngham and J.N. Chiasson, "Charge balance control schemes for cascade multilevel converter in hybrid electric vehicles," IEEE Transactions on Industrial Electronics, vol. 49, no. 5, Oct. 2002, pp. $1058-1064$.

[34] Du Zhong, L.M. Tolbert, J.N. Chiasson, B. Ozpineci, Li Hui and A.Q. Huang, "Hybrid Cascaded H-bridges Multilevel Motor Drive Control for Electric Vehicles," in Proc. 37th IEEE Power Electronics Specialists Conference PESC '06, 18-22 June 2006.

[35] A. Rahiman, U. Kumar and V. Ranganathan, “A novel Fifteen level inverter for photovoltaic power supply system," in Proc. IEEE Industry Applications Society Annual Meeting, IAS2004, Seattle, USA, 2004.

[36] R.L. Naik and K.R.Y. Udaya, "A novel technique for control of cascaded multilevel inverter for photovoltaic power supplies," in Proc. European Conference on Power Electronics and Applications, 11-14 Sept. 2005.

[37] M. Calais, "A transformerless five level cascaded based single phase photovoltaic system," in Proc. IEEE 31st Annual Power Electronics Specialists Conference (PESC’00), Galway, Ireland, 2000.

[38] Chih-Chiang Hua, Chun-Wei Wu and Chih-Wei Chuang, "Control of Low-Distortion 27-Level Cascade Inverter with Three H-Bridge Inverter Modules," in Proc. IEEE International Conference on Industrial Technology, ICIT 2006, pp. 277 - 282 15-17 Dec. 2006.

[39] J. Sabate, L.J. Garces, P.M. Szczesny and Li Qiming,W.F.Wirth, "High-power high-fidelity switching amplifier driving gradient coils for MRI systems," in Proc. IEEE 35th Annual Power Electronics Specialists Conference, PESC 04. vol. 1, pp. 261 - 266, , Aachen, Germany, $20-25$ June 2004.

[40] J. Espinoza and G. Joós, "Power Converter System Simulation Using High Level Languages," in Records of the IEEE 4th Workshop on Computers in Power Electronics, pp 79 - 84, Trois-Rivieres, Canada, August 1994.

[41] T. A. Meynard, M. Fadel and N. Aouda, "Modeling of Multilevel Converters," IEEE Transactions on Industrial Electronics, vol. 44, No. 3, June 1997, pp. $356-364$.

[42] G. Gateau, M. Fadel, P. Maussion, R. Bensaid and T. Meynard, "Multicell Converters: Active Control and Observation of Flying-Capacitor Voltages," IEEE Transactions on Industrial Electronics, vol. 49, No. 5, Oct. 2002, pp. $998-1008$.

[43] C. T. Rim, D. Y. Hu and G. H. Cho, "Transformers as Equivalent Circuits for Switches: General Proofs and D-Q Transformation-Based Analyses," IEEE Transactions on Industry Applications, vol. 26, No. 4, July/August 1990, pp. 777 - 785.

[44] S. B. Han, N. S. Choi, C.T. Rim and G. H. Cho, "Modeling and Analysis of Static and Dynamic Characteristics for Buck-Type Three-Phase PWM Rectifier by Circuit DQ Transformation,” IEEE Transactions On Power Electronics, vol. 13, No. 2, March/April 2001, pp. 323 - 336.

[45] G. Escobar, J. Leyva, J.M. Carrasco, E. Galvan, R. Portillo, M.M. Prats and L.G. Franquelo. "Control of a three level converter used in a synchronous rectifier application," in Proc. IEEE 35th Annual Power Electronics Specialists Conference, PESC 04, Aachen, Germany, 20-25 June 2004.

[46] L. M. Tolbert, F. Z. Peng, and T. G. Habetler, "Multilevel converters for large electric drives," IEEE Transactions on Industry Applications, vol. 35, no. 1, January/February 1999, pp. 36-44. 
[47] R. Teodorescu, F. Blaabjerg, J. K. Pedersen, E. Cengelci, S. Sulistijo, B. Woo, and P. Enjeti, "Multilevel converters - A survey," in Proc. European Power Electronics Conference, 1999, Lausanne, Switzerland.

[48] J. Holtz, "Pulsewidth modulation for electronic power conversion," Proceedings of the IEEE, vol. 82, no. 8, August 1994, pp. 1194-1214.

[49] G. Carrara, S.Gardella, M. Marchesoni, R. Salutari and G. Sciutto, "A new multilevel PWM method: a theoretical analysis," IEEE Transactions on Power Electronics, vol. 7, no. 3, July 1992, pp. $497-505$.

[50] B. P. McGrath and D. G. Holmes, "Multicarrier PWM strategies for multilevel inverters," IEEE Transactions on Industrial Electronics, vol. 49, no. 4, August 2002, pp. 858-867.

[51] M. D. Manjrekar, P. K. Steimer, and T. A. Lipo, "Hybrid multilevel power conversion system: A competitive solution for high-power applications," IEEE Transactions on Industry Applications, vol. 36, no. 3, May/Jun. 2000, pp. 834-841.

[52] O. M. Mueller and J.N. Park, “Quasi-linear IGBT inverter topologies,” APEC'94 Conference Proceedings, pp. 253-259, February 1994.

[53] A. Damiano, M. Fracchia, M. Marchesoni, I. Marongiu, "A new approach in multilevel power conversion," Proceedings of the 7th European Conf. on Power Electronics and Applications (EPE '97), Trondheim, Norway, Sept. 8-10, 1997, pp. 4.216-4.221.

[54] Damiano A., Marchesoni M., Marongiu I., Taffone A.: Optimization of harmonic performances in multilevel converter structures, ISIE'97 Conference, Guimarães, Portugal, July 1997.

[55] K. E. Bornhardt, "Novel modulation techniques for DC-side commutated inverters," Power Electronics and Variable-Speed Drives, 1991, Fourth International Conference on 17-19 Jul 1990, pp. 92 - 97.

[56] M. M. Prats, J.M. Carrasco and L.G. Franquelo, "Effective Algorithm for Multilevel Converters with very low computational cost," IEEE Electronics Letters, Vol. 38, No.22, Oct. 2002, pp.1398-1400.

[57] M. M. Prats, J. M. Carrasco, L. G. Franquelo, "Effective Modulation Algorithm for Three-Level Converters", Proc. of the International Conference on Power Electronics, Intelligent Motion and Power Quality (PCIM'02), Nuremberg (Germany), May 2002, pp. 621-627.

[58] N. Celanovic and D. Boroyevich, “A Fast Space-Vector Modulation Algorithm for Multilevel Three-Phase Converters," IEEE Transactions on Industry Applications, Vol. 37, No. 2, 2001, pp. 637-641.

[59] M. M. Prats, L. G. Franquelo, R. Portillo, J.I. León, E. Galvan and J.M. Carrasco, “A 3-D Space Vector Modulation Generalized Algorithm for Multilevel Converters," IEEE Power Electronics Letters, Vol. 1, No 4, 2003, pp. 110-114.

[60] M. M. Prats, J.I. León, R.Portillo, J. M. Carrasco and L.G. Franquelo, "A Novel Space-Vector Algorithm for Multilevel Converters Based on Geometrical Considerations Using a New Sequence Control Technique," Journal of Circuits, Systems and Computers, Vol. 13. No. 4, 2004 , pp. 845-861.

[61] M. M. Prats, J.M. Carrasco and L. G. Franquelo, "New space vector modulation algorithms applied to multilevel converters with balanced dc-link voltage," Holon Academic Institute of Technology (HAIT) Journal of Science and Engineering B., Vol. 2, Issues 5-6, 2005, pp. 690-714.

[62] J. Pou, D. Boroyevich and R. Pindado, "New feedforward space-vector PWM method to obtain balanced AC output voltages in a three-level neutral-pointclamped converter", IEEE Transactions on Industrial Electronics, Volume 49, Issue 5, pp.1026-1034, Oct. 2002

[63] L. G. Franquelo, J. I. León, M. M. Prats, and R. Portillo, "Space vector modulation techniques for multilevel converters - a survey," Przeglad Elektrotechniczny, No. 4, pp. 56-61. PL ISSN: 0033-2097, 2006.

[64] Simone Buso, Luigi Malesani and Paolo Mattavelli, "Comparison of Current Control Techniques for Active Filter Applications," IEEE Transactions on Industrial Electronics, Vol. 45, No. 5, 1998, pp. 722-729.

[65] Marian P. Kazmierkowski and Luigi Malesani, "Current Control Techniques for Three- Phase Voltage Source PWM Converters: A Survey", IEEE Transactions on Industrial Electronics, Vol. 45, No. 5, 1998, pp. 691-703.

[66] L. G. Franquelo, M. M. Prats, R. Portillo, J. I. León, J.M. Carrasco, E. Galván. M. Perales and J.L. Mora, “Three dimensional space vector modulation algorithm for four-leg multilevel converters using abc coordinates," IEEE Transactions on Industrial Electronics, Vol. 53, No. 2, April 2006, pp. 458 466.

[67] L. Li, D. Czarkowski, Y. Liu, and P. Pillay, "Multilevel selective harmonic elimination PWM technique in series-connected voltage inverters," IEEE Transactions on Industry Applications, Vol. 36, Issue 1, January/February 2000, pp. 160-170.

[68] J. Rodríguez, L. Morán, P. Correa and C. Silva, “A vector control technique for medium-voltage multilevel inverters," IEEE Transactions on Industrial Electronics, vol. 49, no. 4, August 2002, pp. 882-888.

[69] S. Kouro, R. Bernal, C. Silva, J. Rodríguez and J. Pontt, "High performance torque and flux control for multilevel inverter fed induction motors," in Proc. 32nd Annual Conference of the IEEE Industrial Electronics Society (IECON'06), pp. 805-810, Paris, France, Nov. 2006.

[70] N. Celanovic and D. Boroyevich, "A comprehensive study of neutral point voltage balancing problem in three-level-neutral-point-clamped voltage source PWM inverters," IEEE Transactions on Power Electronics, vol. 15, March 2000, pp. 242-249. 
[71] S. Ogasawara and H. Akagi, "Analysis of variation of neutral point potential in neutral-point-clamped voltage source PWM inverters," in Proc. Conf. Rec. IEEE-IAS Annual Meeting, Toronto, Canada, 1993, pp. 965-970.

[72] C. Newton and M. Sumner, "Neutral point control for multi-level inverters: theory, design, and operational limitations," in Proc. Conf. Rec. IEEE-IAS Annual Meeting, New Orleans, LA, 1997, pp. 1136-1343.

[73] J.E. Espinoza, J.R. Espinoza and L.A. Moran, "A systematic controller design approach for neutral-point-clamped three-level inverters," IEEE Transactions on Industrial Electronics, vol. 52, no. 6, Dec. 2005, pp. 1589-1599.

[74] A. Bendre, G. Venkataramanan, D. Rosene and V. Srinivasan, "Modeling and design of a neutral-point voltage regulator for a three-level diode clamped inverter using multiple-carrier modulation," IEEE Transactions on Industrial Electronics, vol. 53, no. 3, June 2006, pp.718-726.

[75] T. A. Meynard, H. Foch, P. Thomas, J. Courault, R. Jakob and M. Nahrstaedt, "Multicell converters: basic concepts and industry applications," IEEE Transactions on Industrial Electronics, Volume 49, Issue 5, Oct 2002 Page(s): 955 - 964

[76] Du Zhong, L.M. Tolbert, J.N. Chiasson and B. Ozpineci, "A cascade multilevel inverter using a single DC source," in Proc. Twenty-First Annual IEEE Applied Power Electronics Conference and Exposition, APEC '06, 19-23 March, 2006.

[77] M. Pérez, J. Rodríguez, J. Pontt and S. Kouro, "Power Distribution in Hybrid Multi-cell Converter with Nearest Level Modulation," in Proc. IEEE International Symposium on Industrial Electronics (ISIE 2007), pp. 736-741, Vigo, Spain, 4-7 June 2007.

[78] Gupta, A. K.; Khambadkone, A. M., "A Space Vector Modulation Scheme to Reduce Common Mode Voltage for Cascaded Multilevel Inverters," Power Electronics, IEEE Transactions on Vol. 22, No.5, Sept. 2007, pp. $1672-1681$.

[79] Poh Chiang Loh; Holmes, D.G.; Fukuta, Y.; Lipo, T.A.; "Reduced common-mode modulation strategies for cascaded multilevel inverters," Industry Applications, IEEE Transactions on Volume 39, Issue 5, Sept.-Oct. 2003 Page(s):1386 - 1395.

[80] Rodriguez, J.; Pontt, J.; Correa, P.; Cortes, P.; Silva, C.; “A new modulation method to reduce common-mode voltages in multilevel inverters," Industrial Electronics, IEEE Transactions on Volume 51, Issue 4, Aug. 2004 Page(s):834 - 839.

[81] Poh Chiang Loh; Holmes, D.G.; Lipo, T.A.; "Implementation and control of distributed PWM cascaded multilevel inverters with minimal harmonic distortion and common-mode voltage," Power Electronics, IEEE Transactions on Volume 20, Issue 1, Jan. 2005 Page(s):90 - 99.

[82] C. Turpin, P. Baudesson, F. Richardeau, F. Forest, T. Meynard, « Fault Management of Multicell Converters,” IEEE Transactions on Industrial Electronics, vol. 49, pp. 988-997, October 2002.

[83] S. Ceballos, J. Pou, I. Gabiola, J. Villate, J. Zaragoza, D. Boroyevich, "Fault-Tolerant Multilevel Converter Topology”, $2006 \quad$ IEEE International Symposium on Industrial Electronics, vol. 2, July 2006 Page(s):1577 - 1582.

[84] J. Rodríguez, P. Hammond, J. Pontt, R. Musalem, P. Lezana and M.J. Escobar, "Operation of a medium-voltage drive under faulty conditions," IEEE Transactions on Industrial Electronics, vol. 52, no. 4, August 2005, pp. 1080-1085.

[85] X. Kou, K. Corzine, and Y. Familiant, “A Unique Fault-Tolerant Design for Flying Capacitor Multilevel Inverter,” IEEE Transactions $\quad \underline{\text { On }} \underline{\text { Power }}$ Electronics, vol. 19, no. 4, July 2004, pp. 979-987.

[86] P. Lezana, J. Rodríguez and R. Aguilera, "Fault Detection on Multicell Converter Based on Output Voltage Frequency Analysis," in Proc. Industrial Electronics Conference, IECON'06, 7-10 November, Paris, France, 2006.

[87] E. da Silva, W. Lima, A. de Oliveira, C. Jacobina, H. Razik, "Detection and compensation of switch faults in a three level inverter", 37th IEEE Power Electronics Specialists Conference, 2006. PESC '06. 18-22 June 2006 Page(s):1 - 7.

[88] S. Bernet, D. Krug, S. Fazel, and K. Jalili, "Design and comparison of $4.16 \mathrm{kV}$ neutral point clamped, flying capacitor and series connected H-bridge multi-level converters," in 40th Conf. Rec. IAS Annu. Meeting, Hong Kong, Oct. 2005, pp. 121-128.

Leopoldo G. Franquelo (M'84-SM'96-F'05) was born in Málaga, Spain. He received the M.Sc. and Ph.D. degrees in electrical engineering from the University of Seville, Seville, Spain, in 1977 and 1980, respectively. In 1978, he joined the University of Seville and is Professor since 1986. From 1998 to 2005, he has been the Director of the Department of Electronic Engineering.

He was the Vice-President of the Industrial Electronics Society (IES) Spanish Chapter (2002-2003), member at Large of the IES AdCom (2002-2003). He has been the Vice-President for Conferences of the IES since 2004, in which he has also been a Distinguished Lecturer since 2006. He has been an Associated Editor for the IEEE Transactions on Industrial Electronics since 2007.

His current research interest lies on modulation techniques for multilevel inverters and its application to power electronic systems for renewable energy systems. He leads a large research and teaching team in Spain. In last five years, he is author of 40 publications in international journals and 165 in international conferences. He is holder of ten patents and advisor for ten Ph.D. dissertations and 96 R\&D projects. 
Jose Rodriguez (M'81-SM'94) received the Engineer's degree in electrical engineering from the Universidad Técnica Federico Santa Maria (UTFSM), Valparaíso, Chile, in 1977 and the Dr.Ing. degree in electrical engineering from the University of Erlangen, Germany, in 1985.

Since 1977, he has been a Professor with the UTFSM, where from 2001 to 2004, he was appointed as Director of the Electronics Engineering Department, from 2004 to 2005, he was a Vice Rector of academic affairs, and since 2005, he has been a Rector. During his sabbatical leave in 1996, he was responsible for the Mining Division, Siemens Corporation, Santiago, Chile. Prof. Rodriguez has been an active Associate Editor with the IEEE Power Electronics and Industrial Electronics Societies since 2002. He has served as Guest Editor of IEEE Transactions on Industrial Electronics in four opportunities.

$\mathrm{He}$ has a large consulting experience in the mining industry, particularly in the application of large drives like cycloconverter-fed synchronous motors for SAG mills, high-power conveyors, controlled ac drives for shovels, and power-quality issues. His main research interests include multilevel inverters, new converter topologies, and adjustable speed drives. He has directed over 40 R\&D projects in the field of industrial electronics, he has coauthored over 50 journal and 130 conference papers, and contributed with one book chapter. His research group has been recognized as one of the two centers of excellence in engineering in Chile in the years 2005 and 2006.

Jose I. Leon (S'04-M’07) was born in Cádiz, Spain, in 1976. He received the B.S., M.S., and Ph.D. degrees in telecommunications engineering from the University of Seville (US), Seville, Spain, in 1999, 2001, and 2006, respectively.

In 2002, he joined the Power Electronics Group, US, working on R\&D projects. He is currently an Associate Professor with the Department of Electronic Engineering, US. His research interests include electronic power systems, modeling, modulation, and control of power-electronic converters and industrial drives, and power quality in renewable generation plants.

Samir Kouro (S'04) was born in Valdivia, Chile, in 1978. He received the Eng. and M.Sc. degrees in electronics engineering in 2004 from the Universidad Técnica Federico Santa María (UTFSM), Valparaíso, Chile, where he is currently pursuing the Ph.D. degree. In 2004 he joined the Electronics Engineering Department UTFSM as Research Assistant.

In 2004, he was distinguished as the youngest researcher of Chile in being granted with a governmental-funded research project (FONDECYT) as Principal Researcher. His research interests include power converters and adjustable speed drives.

Ramon Portillo (S'06) was born in Seville, Spain, in 1974. He received the B.S. and M.S. degrees in industrial engineering from the University of Seville (US) in 2002, where he is currently working toward the Ph.D. degree in electrical engineering with the Power Electronics Group.

In 2001, he joined the Power Electronics Group, working on R\&D projects. Since 2002, he has been an Associate Professor with the Department of Electronic Engineering, US. His research interests include electronic power systems applied to energy conditioning and generation, power quality in renewable generation plants, applications of fuzzy systems in the industry and wind farms, and modelling and control of power-electronic converters and industrial drives.

Maria A. M. Prats (M'04) was born in Seville, Spain, in 1971. She received the Licenciado and Doctor degrees in physics from the University of Seville (US), Seville, Spain, in 1996 and 2003, respectively.

In 1996, she joined the Spanish Aerospatial Technical National Institute (INTA), where she worked in the Renewable Energy Department. In 1998, she joined the Department of Electrical Engineering, University of Huelva, Spain. Since 2000, she has been an Assistant Professor with the Department of Electronics Engineering, US. Since 2006 she is IEEE WIE Spanish section President. Her research interests focus on multilevel converters and fuel-cell power-conditioner systems. She is involved in industrial applications for the design and development of power converters applied to renewable-energy technologies. 


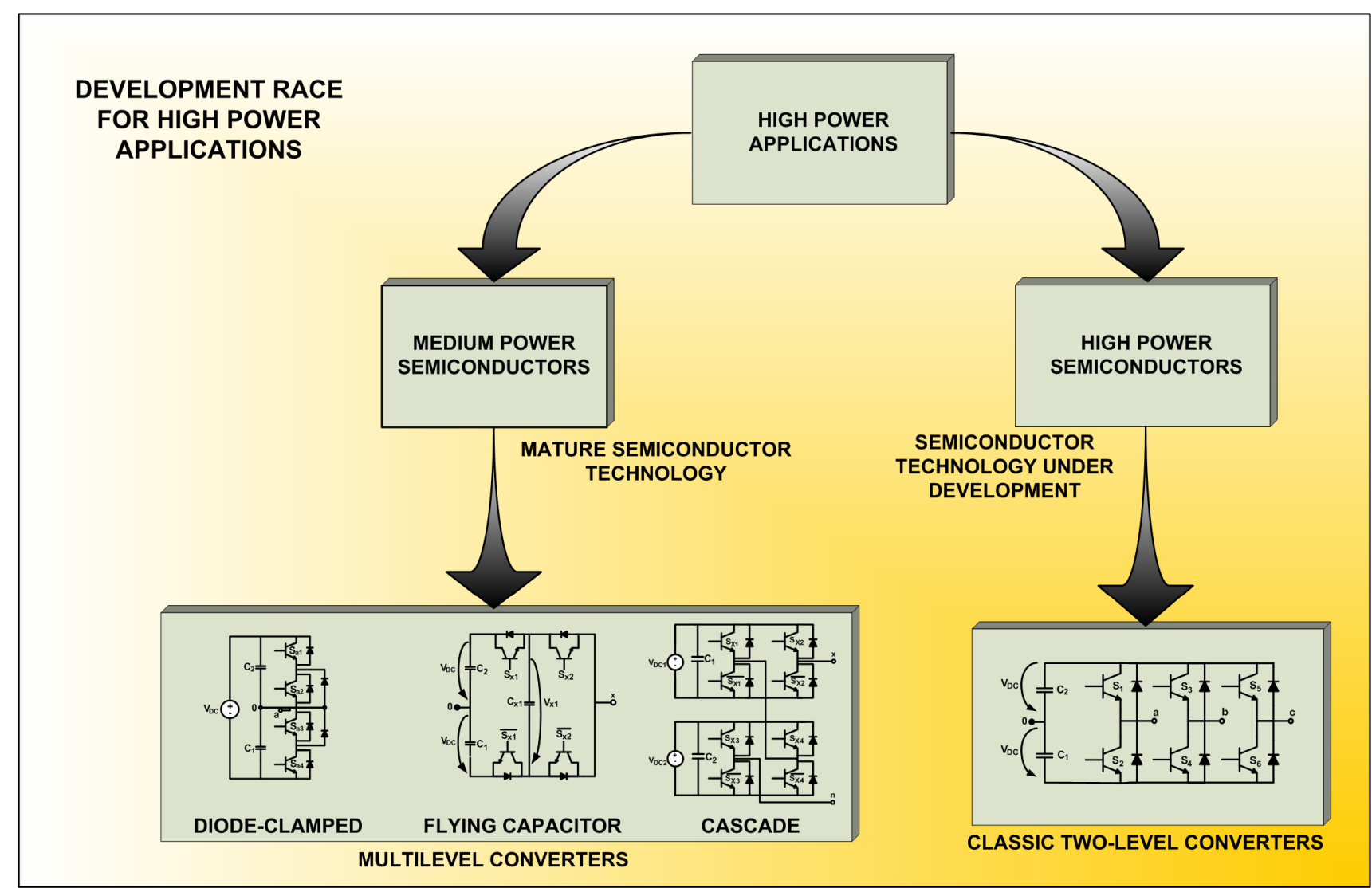

Fig. 1. Classic two-level power converters versus most common multilevel power converters. Development race between two different solutions in high power applications. 

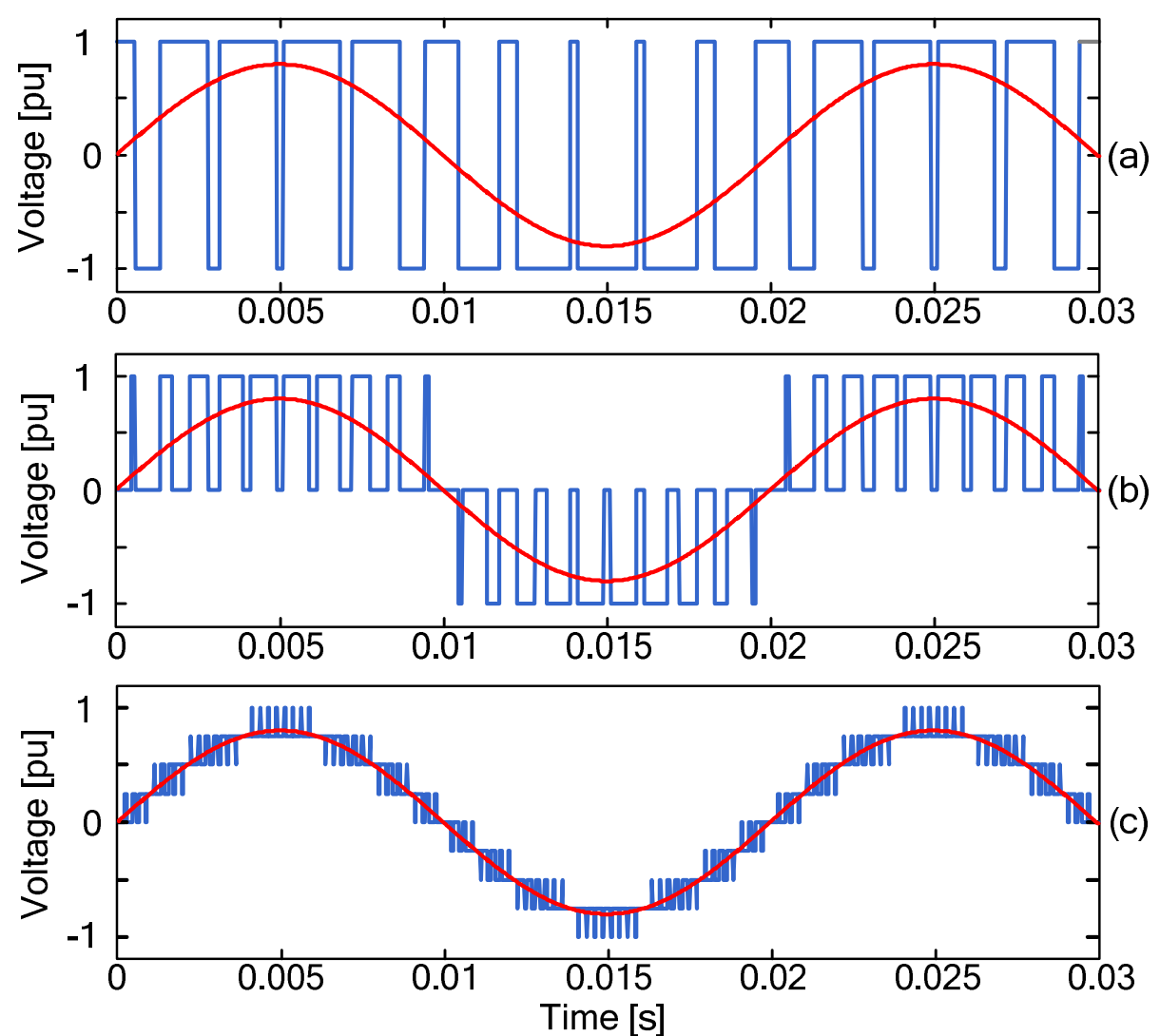

Fig. 2. Comparison of output phase voltage waveforms: a) two level inverter. b) three level inverter. c) nine level inverter. 


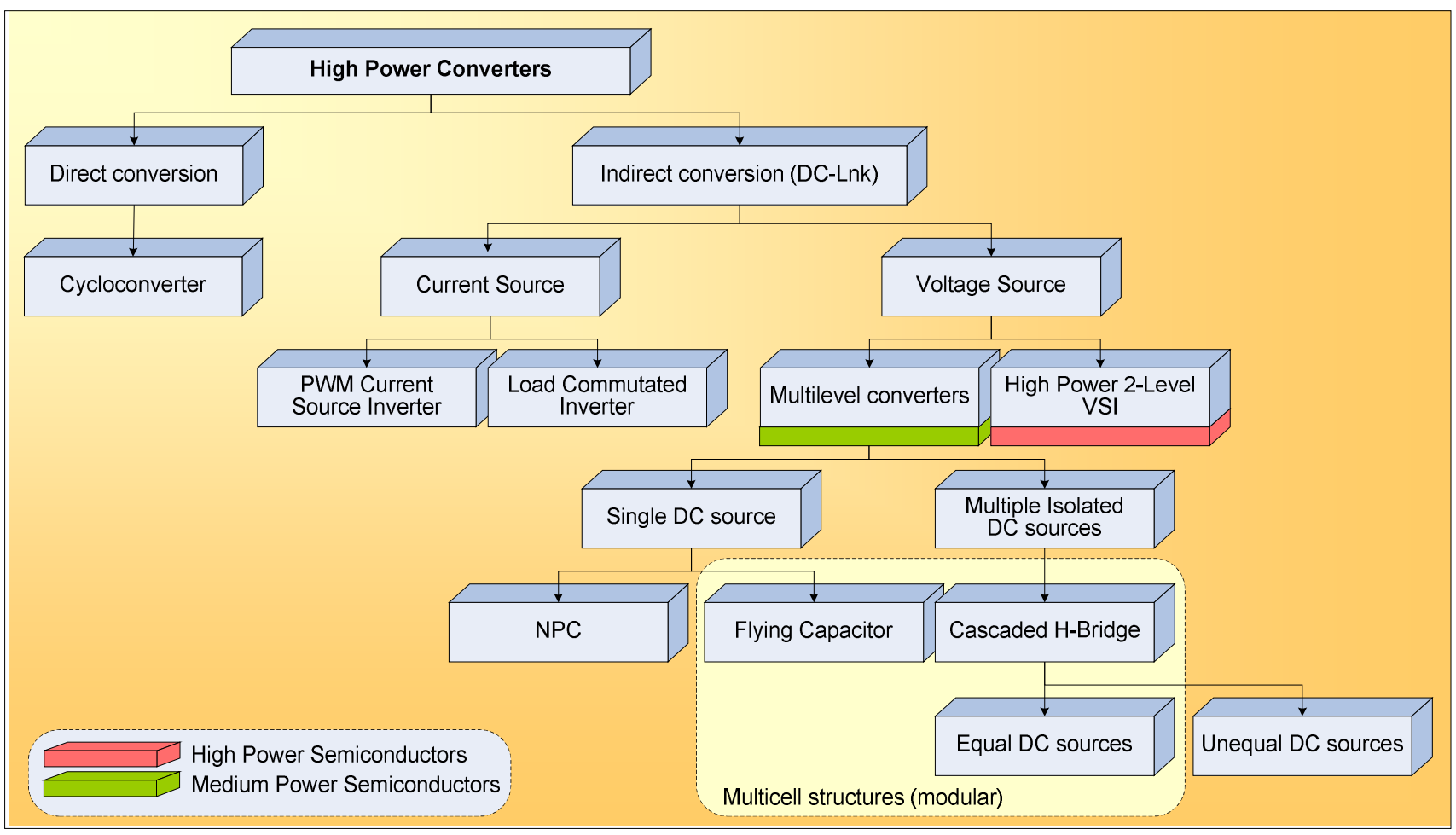

Fig. 3. High power converters classification. 


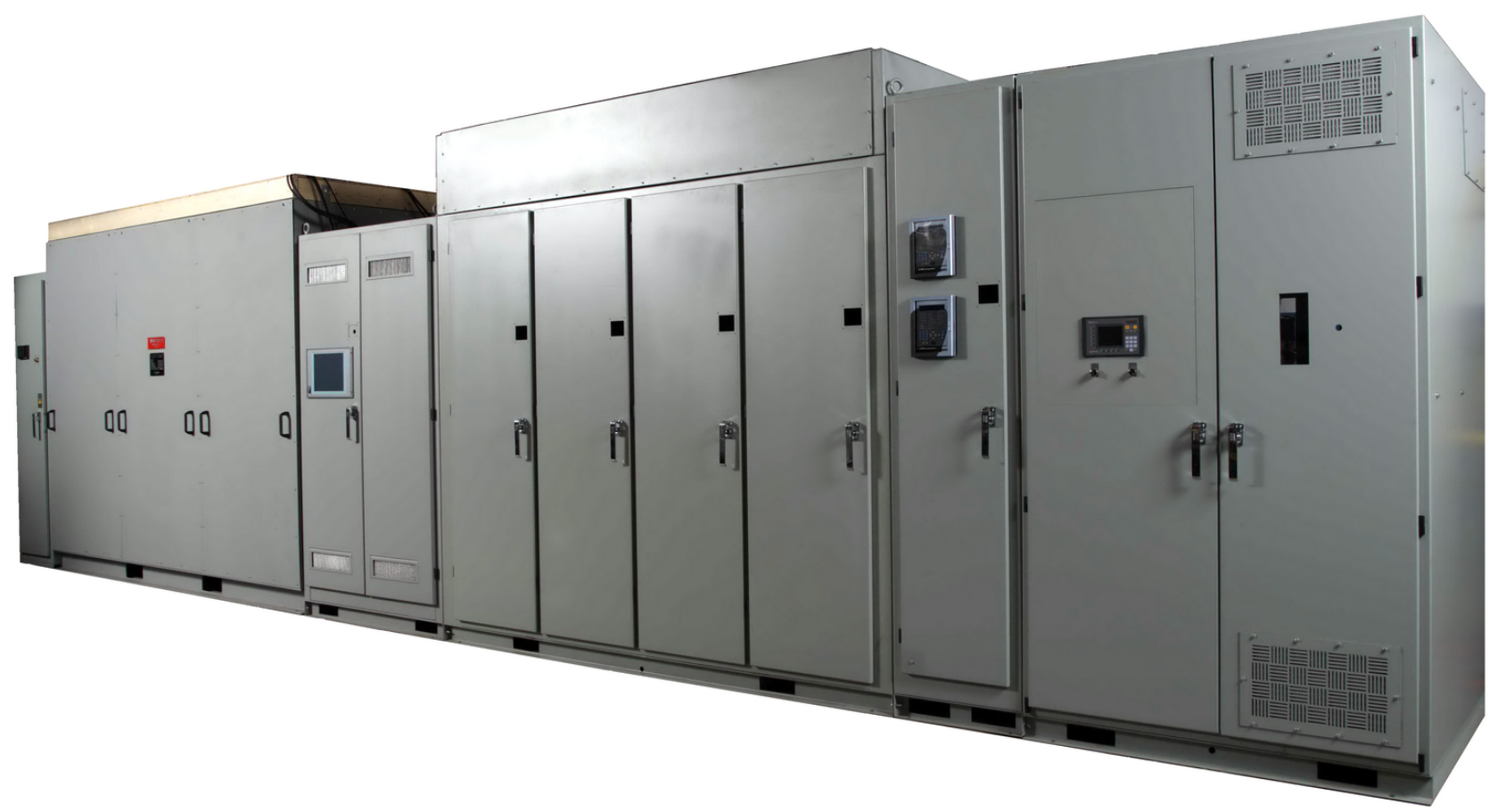

Fig. 4. Multilevel cascaded H-bridge converter with six cells per phase, 13 levels, $15 \mathrm{MW}$ for regenerative drives 


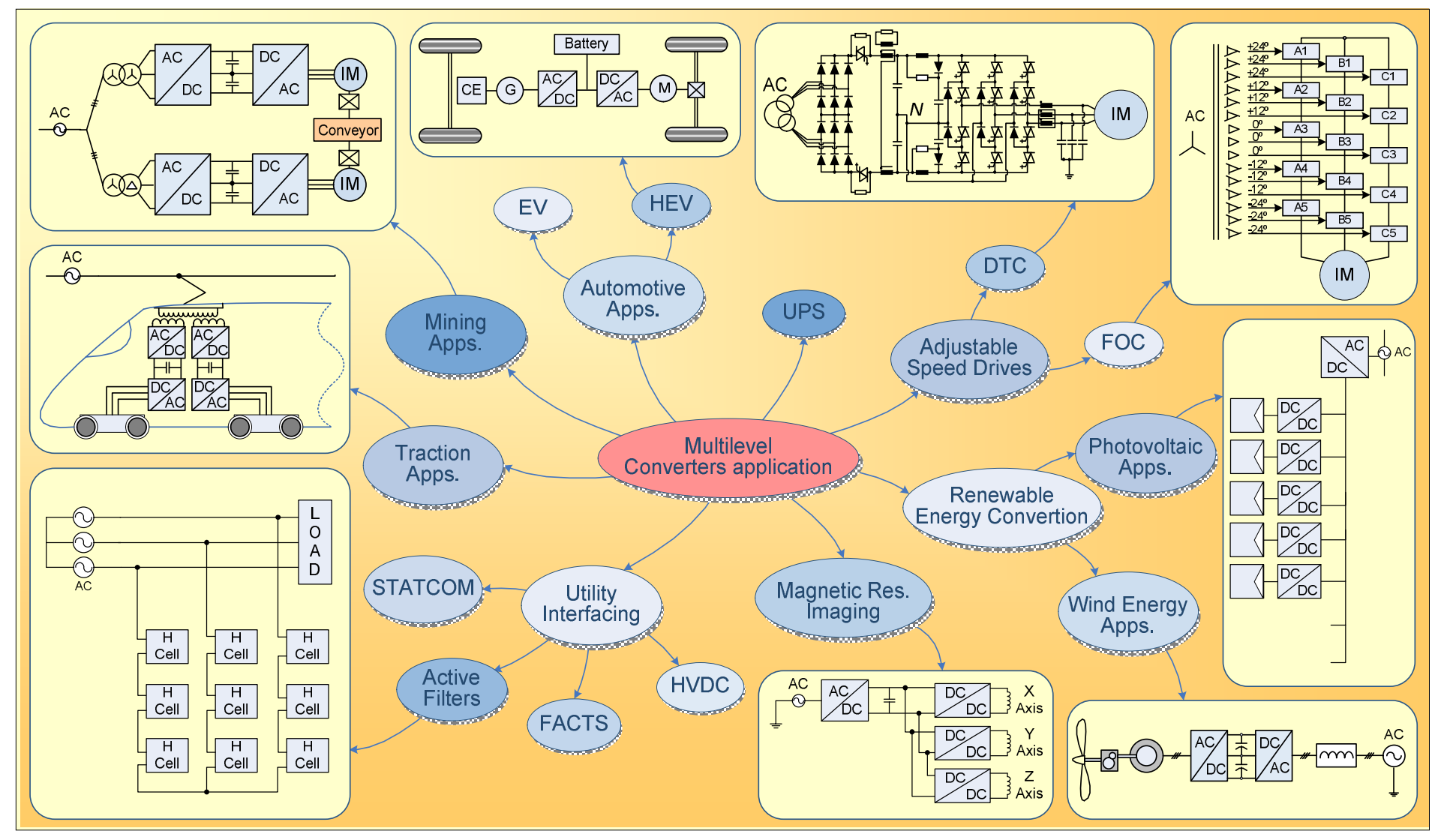

Fig. 5. Multilevel converter driven applications overview. 


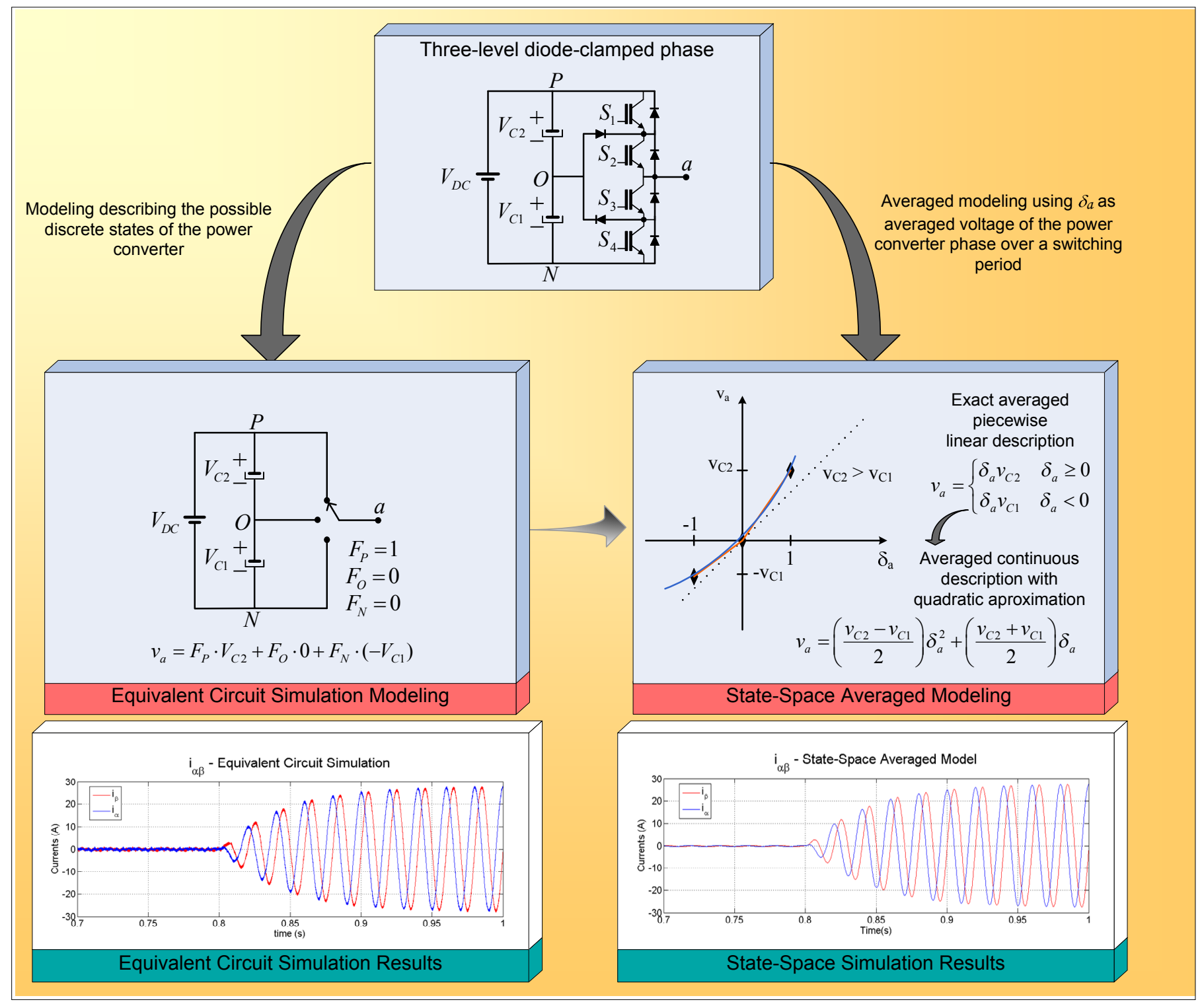

Fig. 6. Equivalent circuit and State-Space Modeling of multilevel converters 


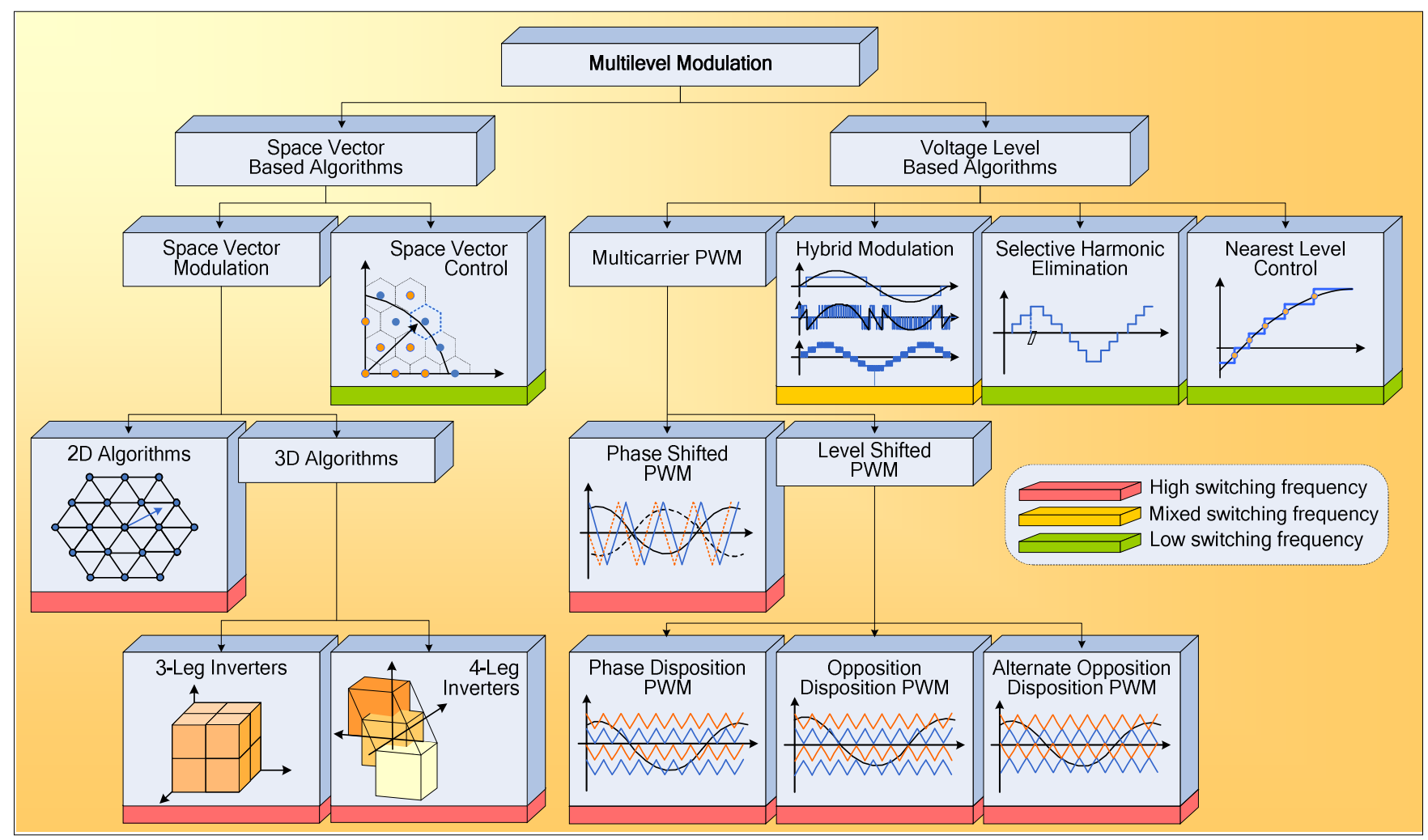

Fig. 7. Multilevel inverter modulation classification. 


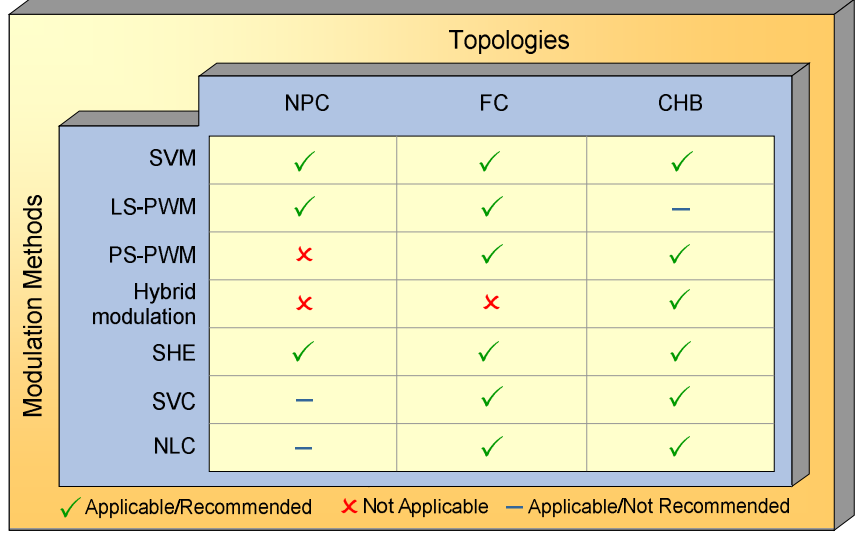

Fig. 8. Applicability of modulation methods to multilevel topologies. 